I am tempted to recall " the Weasel" as immortalized in the traditional English nursery rhyme!-I am, etc.,

The Alfred Hospital,

J. B. Morley.

Victoria, Australia.

\section{Ménière's Disease}

SIR,-The points which Mr. M. A. Falconer (29 May, p. 1433) and Mr. W. McKenzie (20 February, p. 522) make are of great importance in the treatment of Ménière's disease. In my experience surgery of any form in Ménière's disease is becoming necessary much less often. As Mr. McKenzie states, surgery is rarely required and usually only when the disease has progressed so far that recovery with medical treatment fails, and by this time the hearing is seldom worth preserving. I doubt whether it will ever be possible to treat every case of Ménière's disease early enough to relegate all forms of surgical treatment to the history of the disease; but in the past two decades we have advanced far in this direction.-I am, etc.,

Market Rasen,

M. SPENCER HARRISON.

Lincs.

\section{Geophagia and Breath-holding}

SIR,-May I draw your attention to two features of iron-deficiency anaemia which are common in the Western Transvaal but which are not mentioned by Professor J. H. Hutchison in his article "Anaemia in Infancy and Childhood" (13 March, p. 701). The first is geophagia or sand-eating. Curiously parents rarely complain of this and only admit to it on direct questioning. In 50 cases the commonest complaint was " $\mathrm{He}$ doesn't eat a thing," but questioning reveals that the infant drinks large volumes of milk. Iron therapy and reduction of the milk to 1 pint ( $568 \mathrm{ml}$.) or less daily results in cure of this symptom. On my recent visit to London I had the impression that pica takes the form of eating flaking paint rather than sand, as sand is difficult to find in large cities. Further it is often associated with leadpoisoning. According to Gutelius ${ }^{1}$ these cases do not respond as well to iron therapy.

The second symptom of interest is breathholding spells. A quarter of my cases ${ }^{2}$ were breath-holders, and I have the impression that these cases respond better to intramuscular iron than oral iron. I think that the reason that we have missed the association between breath-holding and iron deficiency is that breath-holding is regarded as a behaviour disorder and the mother is dismissed with a pat on the back and reassurance that the child "Will grow out of it." Anaemia is not always apparent and many cases have red cheeks and pink conjunctivae. Nevertheless smears nearly always reveal at least a few hypochromic cells. Intramuscular iron seems to be very effective in most cases. In fact I have only met one case that did not respond entirely to intramuscular iron, but, as his mother said, "He seems to have more difficulty in holding his breath now." The number of bouts were considerably reduced. It is surprising that in many cases only $2-4 \mathrm{ml}$. of parenteral iron seems sufficient to reduce both pica and breath-holding, even in cases where this dose is insufficient to cure the anaemia.

I suspect that tissue deficiency of iron is more important than anaemia per se, but I cannot go into all the reasons for this. I do suggest that practitioners try to treat their breath-holders with 1-2 injections of intramuscular iron even if the anaemia is not gross. Thereafter the residual anaemia can be corrected by oral therapy.

I would very much like to hear the experience of other practitioners with pica and breath-holding either through your columns or by writing direct to me.-I am, etc.,

$$
\begin{aligned}
& \text { 402 U.B.S. Buildings, Pincus CATZEL. } \\
& \text { Klerksdorp, } \\
& \text { Republic of South Africa. } \\
& \text { Reperences } \\
& 1 \text { Gutelius, M. F., Pediatrics, 1963, 31, } 1056 . \\
& 2 \text { Catzel, P., Med. Proc., 1964, 10, 439. }
\end{aligned}
$$

\section{REPERENCES}

\section{Eclipse of Hysteria}

SIR,-With regard to Dr. Eliot Slater's lecture on hysteria (29 May, p. 1395) the outstanding example in recent years of hysterical manifestations following organic disease was the remarkable series of events that followed the Royal Free disease in London in the early 1950s.

In persons of previously sound personality who had recently contracted this form of acute meningo-encephalitis, "hysterical paralysis" of limb, glove-and-stocking anaesthesia, "hysterical blindness," and other apparently functional ailments occurred with such frequency that there seemed no doubt but that they were related to the underlying organic inflammatory process, which was demonstrated in a few fatal cases. Some were left with permanent personality changes that led a few to suicide.

In recent years this was one of the best opportunities to enable us to demonstrate a causative lesion in patients showing hysterical traits and should lead us finally away from the old concept that hysteria is the result of emotional conflict in one facing a dilemma.I am, etc.,

Bantry, Co. Cork. Eugene F. MURPhy.

\section{Giggle Micturition-A Misnomer?}

SIR,-In his report of micturition induced by giggling, discussed in your leading article of 3 April (p. 879), Mac Keith ${ }^{1}$ defines giggling as a special type of laughter associated with a high degree of excitement, and often anxiety, being difficult to control, having about it an element of "naughtiness," and occurring after the age of 5 . However, giggling is surely a particular pattern of laughing behaviour, having a halfsuppressed, tittering quality, and it cannot be defined satisfactorily in terms of psychological and social associations which it may share with other types of laughter. A 19year-old female studied in this department had involuntary micturition only when laughter was associated with aggressive feelings or she felt everything about her was " in chaos and confusion." But this laughter was entirely unrestrained, and could scarcely be described as giggling. The other features of her condition, however, were very like those of giggle micturition.

On close reading of Mac Keith's paper it is not clear in some of the children that the laughter in fact had the particular features described above; neither do they appear in the brief mention by Dunbar ${ }^{2}$ of two adult cases of involuntary micturition on laughing. In his discussion of diurnal enuresis Kanner, ${ }^{3}$ having remarked that this is an uncommon condition, notes that patients frequently report its association with emotional states, particularly laughter or, less often, fear.

Mac Keith himself finds no reason for attributing giggle micturition to the special features of giggling, and the evidence suggests that it may also be associated with other patterns of laughing behaviour. Ethological analysis may eventually tell us what these might be and what they might have in common with giggling. However, it seems likely that both their behavioural characteristics and their associated emotions will be ambivalent.

"Once a clinical picture has a name it is more easily recognized"1_but a partially misleading name may delay the full understanding of a syndrome. It is obviously desirable to define a subgroup within so diffuse a problem as diurnal enuresis, but it is difficult to choose a name which includes what we may reasonably regard as established and leaves out what is debatable. My own suggestion, "ambivalent laughter micturition," is clumsier than Dr. Mac Keith's, but perhaps represents more closely our present understanding of this distressing complaint.-I am, etc.,

\section{W. Millard.}

Department of Psychiatry, Queen Elizabeth $\mathrm{H}$
Birmingham 15 .

\section{REPERENCES}

Mac Keith, R. C., Guy's Hosp. Rep., 1964, 113,

250.
Dunbar, F., Emotions and Bodily Changes, p. 490, 4th ed., 1954. Columbia University p. 490, 4th ed., Kanner, L., Child Psychiatry, p. 441, 3rd ed., Thomas, Springfield.

\section{Co-existent Cretinism and Klinefelter's Syndrome}

SIR,-I was interested to read the report of Drs. J. A. Boyle and E. M. McGirr on co-existing cretinism and Klinefelter's syndrome (1 May, p. 1170). The following similar case lends support to their conviction that the association of the two conditions is not fortuitous.

A. B., a first-born white male child, was delivered five weeks prematurely on 15 November 1955. Birth weight was 4 lb. 13 oz. $(2,183$ g.) and jaundice persisted for several weeks. From the outset there was poor weight gain, vomiting, and constipation. He was extremely irritable and showed marked delay in all aspects of development. At 8 months he weighed only 8 lb. $(4,082$ g.).

I saw him first at 2 years and 11 months of age, when he appeared to be a typical cretin. $\mathrm{He}$ was a stunted and mentally retarded child who could barely stand with support and had no words. The weight was $18 \mathrm{lb}$. $(8,165 \mathrm{~g}$ ) height 28 in. $(70 \mathrm{~cm}$.), span 26 in. $(65 \mathrm{~cm}$.), and crown-rump measurement $11 \frac{1}{2}$ in. $(29 \mathrm{~cm}$.). There was no goitre. The skin was dry and 
scaly and the scalp hair dry and sparse with many areas of alopecia. The teeth were yellowish-green in colour and very carious. A widespread, loud, coarse pansystolic murmur was heard, maximal in the mitral area. Bloodpressure in the right arm was $100 / 60$. The penis appeared normal in size and both testes were palpable in the scrotum. Radiologically there was great delay in epiphysial development, stippling of the epiphyses of the femoral heads, and deformity of the first lumbar vertebra. Bone texture itself was normal and no nephrocalcinosis was seen. Protein-bound iodine was 3 micrograms $/ 100 \mathrm{ml}$., and total cholesterol 342 mg./100 ml. Hypercalcaemia was persistently present (range $11.6 \mathrm{mg}$. to $12.8 \mathrm{mg} . / 100 \mathrm{ml}$.) Blood urea was $46 \mathrm{mg} . / 100 \mathrm{ml}$., serum phosphate $4 \mathrm{mg} . / 100 \mathrm{ml}$, and all other investigations normal. He failed to show improvement on oral thyroid and later prednisolone was given in an attempt to reduce the hypercalcaemia without much benefit.

In 1959, at the age of $3 \frac{1}{2}$ years, I referred him to Professor (then Doctor) J. O. Forfar, in Edinburgh, for further evaluation. In the course of investigation Professor Forfar found that buccal smears were chromatin positive. The Medical Research Council Cytogenetics Unit, in Edinburgh, performed two separate chromosome counts obtained from marrow culture, and in both the tally was 47 .

The hypercalcaemia settled spontaneously and the systolic murmur disappeared. He has since made good physical progress on thyroid, but is mentally retarded (I.Q. $48 \%$ ), almost certainly from the delay in initiating treatment. $\mathrm{He}$ has sustained three fractures of limb bones following relatively slight trauma, but all healed quickly.

The association of hypercalcaemia with hypothyroidism is also of considerable interest. Naylor ${ }^{1}$ reported a similar case who showed in addition sclerotic changes at the epiphyses of long bones and nephrocalcinosis. More recently Job et al. ${ }^{2}$ cite two further cretins who had hypercalcaemia and hypercalciuria which became worse after the initiation of thyroid treatment. They incriminate the known hypersensitivity of cases of hypothyroidism to vitamin $D$ and advise assessment of previous vitamin-D intake, together with surveillance of serum- and urinecalcium levels. As in the case cited above, their infants also commenced treatment late (at 19 months and 13 months, respectively). -I am, etc.,

Bulawayo, Rhodesia. M. A. KIBEL.

\section{REFERENCES} 1 Naylor, J. M., Arch. Dis. Childh., 1955, 30, 165.
:2 Job, J.-C., Ribierre, M., and Badoual, J., Arch. franç. pédiat., 1963, 20, 1033

\section{Doctors' Pay}

SIR,-I hope the medical profession in Britain is not going to back down over the question of remuneration.

I have recently arrived here, and find that the surgery consultation fee is equal to a year's capitation fee in Britain (double the amount, out of hours); and I can earn as much doing a week-end locum as I could in a week as an assistant in general practice at home.

Surprisingly, the pressure on beds is in the private hospitals (as most people are insured); and the public hospitals, which are free, have empty beds in the ward-a situation unknown to me in England.

The consultation fee does not seem to stop people wanting attention for minor ailments, but it is not so annoying having to visit someone with a cold when you are being paid 2 gns. for your efforts (most of the fee is refunded to the patient by the State insurance scheme).

It is not until you get to a country like this that you realize the extent to which the British doctor is being underpaid.- I am, etc.

$$
\begin{aligned}
& \text { Queen Victoria Memorial } \\
& \text { Hospital, } \\
& \text { Melbourne, Australia. }
\end{aligned}
$$

\section{“To-morrow's Parents"}

SIR,-Dr. F. E. Graham-Bonnalie (22 May, p. 1379) questions the usefulness of pursuing the Association's exhortation to Divisions to set up standing groups to implement the recommendations of the Conference on Venereal Disease and Young People, " To-morrow's Parents."

Clearly he appreciates the "atmosphere" of our present social state and no less the trends in the behaviour of youth. Like so many of us the steadily increasing, if marginal, growth of antisocial and irresponsible behaviour distresses him. It is a pity, therefore, that he abandons himself so readily to nihilism. Of all the symptoms of society in distress, the rising incidence of venereal infections has the clearest medical connexions. Here is an area in which doctors can give a lead, however humbly. A start should be made somewhere and the Association offers the opportunity.

It is, of course, not only youth itself which needs support. There is an ever increasing number of distraught parents. Many of these would welcome some general and particular guidance in establishing or re-establishing their authority in the home. Our standards as to when a boy or girl is in need of care, protection, or control are much in need of reviewing. Parents at the moment have too little help in this regard.

The age limit of culpability was raised from 8 to 10 years some time ago. There are hopes in some quarters that it will again be raised, perhaps to somewhere in the early teens. Strengthening father's hand would give some hope of inculcating " the basic need for goodness" which Dr. Graham-Bonnalie desires. In the meantime I suggest we do what we can. - I am, etc.,

Sheffield.

R. S. MORTON.

\section{Activities of the B.M.A.}

SIR,-II write to support the letters of Drs. J. G. Bancroft and R. Payne (29 May, p. 1438). They are quite righe when they ask for the activities of the Association to be kept under some restraint. When I contemplate the madness of our so-called organization, with its duplicated and overlapping committees, and its inability to act until an explosion of feeling from the rank and file occurs, then I marvel that the old machinery works as well as it does. Surely it is time to streamline this ponderous establishment? The proposed increase in subscriptions might then prove to be unnecessary.-I am, etc.,

Paignton, Devon.

J. F. BURDON.

\section{Africa's Need}

SIR,-Dr. J. R. L. Roberts's plan (5 June, p. 1494) whereby young doctors would be seconded as medical officers to African countries for periods of 3 to 6 months has two major drawbacks. (1) To provide up to four return air-passages for twelve months' work by one doctor would be prohibitively expensive no matter how co-operative the air-lines. There would, too, be many additional costs such as clothing and housing. (2) This expensive doctor, moreover, would be largely quite useless to the African community. He would arrive with little or no experience of tropical disease or of the presentation of illness in the unsophisticated African. $\mathrm{He}$ would have no experience of work in grossly under-doctored areas-and he might well find himself faced with a "crowded surgery" not of 20 or 30 patients but of 200 . However skilful at diagnosis and in the treatment of minor maladies, if he could not undertake the routine major surgery-giving the anaesthetics at the same time-he would in many areas prove to be worse than useless. An ability to sort out those cases which do not need a "specialist" is not nearly enough.

Dr. Roberts's diagnosis is accurate but his therapeutics are faulty. As one who has spent many years in practice overseas, I know only too well that " temporary absence abroad removes one from the memory of potential employers ... [and] can tip the scales against someone obtaining . . . consultant post." At one of three interviews which I attended a member of the Board opened the proceedings by asking me not to describe my professional work overseas. By contrast, great interest was shown in my 18 months' National Service 14 years before. At another, the chairman opened his interrogation by commenting that I had spent many years in Africa and must have gained a great deal of experience there, "but," he continued, "tell me, doctor, do you see many African patients in this country?"

If secondment of doctors for adequate periods of time is to be this country's contribution to the medical manpower shortage in Africa, the remedy for the career-problem of such doctors lies not in sending them for totally inadequate periods (and, in any case, an attitude which suggests that British doctors think they can solve Africa's medical problems in their long week-ends is not one that is likely to endear them to Africans) but in ridding the hospital service of its parochialism. Just as our trade unions have to learn that "Made in Britain (no matter how badly)" is not synonymous with "Better than Foreign Manufacture," so the N.H.S. Establishments have yet to appreciate that "Learned in Britain (no matter how little)" is not necessarily synonymous with "Better than learned elsewhere"-this despite the fact that every year 500 more doctors intimate that they consider the practice of medicine in other countries to be superior to that in Britain

So long as advancement in the hospital service depends little more on-or less onwhat he knows and what he can do than on whom he knows and what they can do for him, an aspiring hospital consultant will have to reject any notion of temporary work in Africa-and the loss will be his, every bit as much as Africa's.-I am, etc., 